\title{
ZAKRES PODMIOTOWY USTAWY O PRZECIWDZIAŁANIU PRANIU PIENIĘDZY W ŚWIETLE ZNOWELIZOWANYCH PRZEPISÓW
}

\section{WSTĘP}

Ustawa z 1 marca 2018 r. o przeciwdziałaniu praniu pieniędzy oraz finansowaniu terroryzmu weszła w życie 13 lipca 2018 r. ${ }^{1}$ Uchyliła ona zarazem postanowienia obowiąującej w tym zakresie ustawy z 16 listopada 2000 r. ${ }^{2}$, czyniąc jednocześnie zadość potrzebie implementowania do krajowego porządku prawnego dyrektywy Parlamentu Europejskiego i Rady (UE) 2015/849 z 20 maja 2015 r. $^{3}$ Podobnie jak w przypadku poprzednio obowiąującej usta$\mathrm{wy}^{4}$, tudzież jej kolejnych nowelizacji, tak i w odniesieniu do ustawy z 1 marca 2018 r. zasadniczym (żeby nie stwierdzić, że jedynym) motywem jej uchwalenia była potrzeba dostosowania polskich przepisów do unormowań unijnych. Nie może to ujść uwadze, w szczególności jeżeli podjać próbę analizy zmian wprowadzonych do polskich przepisów. W każdym bowiem przypadku ocena przyjętych rozwiązań prawnych będzie wymagała - z jednej strony - kontekstu w postaci status quo na arenie wspólnotowej w omawianym względzie; z drugiej jednak - może prowadzić do niezbyt optymistycznej refleksji, że tak ujęta ratio legis ustawy z 1 marca 2018 r. stała się powodem zbytniego pośpiechu legislacyjnego, co nie pozostaje obojętne z punktu widzenia kształtu obowiąujących uregulowań ${ }^{5}$. Kwestia nabiera szczególnej doniosłości, jeśli zważyć, że nieuniknione są kolejne nowelizacje u.p.p. ${ }^{6}$ Uczynienie powodem zmian wyłącznie potrzeby dostosowania polskich przepisów do wymagań stawianych

1 Ustawa z 1 marca 2018 r. o przeciwdziałaniu praniu pieniędzy oraz finansowaniu terroryzmu (potocznie określana mianem ustawy AML - ang. anti-money-laundering), t.jedn.: Dz. U. 2019, poz. 1115 (dalej jako: u.p.p. lub ustawa z 1 marca 2018 r.).

${ }^{2}$ Ustawa z 16 listopada 2000 r. w pierwotnym brzmieniu nosiła tytuł: ustawa o przeciwdziałaniu wprowadzaniu do obrotu finansowego wartości majątkowych pochodzących z nielegalnych lub nieujawnionych źródeł (Dz. U. Nr 116, poz. 1216). Na mocy nowelizacji z 27 września 2002 r. jej zakresem objęto dodatkowo przeciwdziałanie finansowaniu terroryzmu (Dz. U. 2002, Nr 180, poz.1500).

${ }^{3}$ IV dyrektywa AML - dyrektywa Parlamentu Europejskiego i Rady (UE) 2015/849 z 20 maja 2015 r. w sprawie zapobiegania wykorzystywaniu systemu finansowego do prania pieniędzy lub finansowania terroryzmu, Dz. Urz. UE L nr 141: 73-117 (dalej jako: IV dyrektywa AML).

${ }^{4}$ Por. Pływaczewski (2002): 43-52, a także: Pływaczewski, Filipkowski (2003): 359-362.

5 Najlepszym tego przykładem jest ustawa z 16 października 2019 r., nowelizująca u.p.p. (Dz. U. 2019, poz. 2088).

${ }^{6}$ W szczególności implementowanie do dnia 3 grudnia 2020 r. VI dyrektywy AML. 
przez Unię Europejską może rodzić także obawy o to, czy krajowy ustawodawca podoła „nadążaniu” za zmieniającymi się w sporym tempie przepisami wspólnotowymi. Uzasadnieniem tego może być chociażby fakt, że jeszcze przed formalnym wejściem w życie polskiej ustawy z 1 marca 2018 r. ${ }^{8}$ Parlament Europejski przyjął kolejna, „piątą już dyrektywę AML/CFT, zmieniająca wspomnianą już dyrektywę Parlamentu Europejskiego i Rady (UE) 2015/849 (a także dwie inne dyrektywy: dyrektywę 2009/138/WE oraz 2013/36/UE) ${ }^{9}$. Dyrektywa Parlamentu Europejskiego i Rady (UE) 2018/843 z 30 maja 2018 r. (nazywana V dyrektywą AML) ${ }^{10}$ wprowadziła zmiany odnoszące się między innymi do zakresu podmiotów zobowiązanych do przeciwdziałaniu praniu pieniędzy oraz finansowaniu terroryzmu, funkcjonowania rejestru beneficjentów rzeczywistych oraz obrotu walutami wirtualnymi.

Termin na przetransponowania do krajowego porządku prawnego V dyrektywy AML upłynął 10 stycznia 2020 r. Tymczasem część jej postanowień nie została nadal implementowana do rodzimej ustawy. Warto zwrócić uwagę na te z jej postanowień, które należałoby uwzględnić w stosownej nowelizacji u.p.p.

Bezdyskusyjnie jednak największy wpływ na zmianę polskich przepisów w zakresie przeciwdziałania praniu pieniędzy wywarła IV dyrektywa AML ${ }^{11}$. Rozwiązania prawne przyjęte w ustawie z 1 marca 2018 r. stanowią w dużej mierze wyraz uwzględnienia w polskim porządku prawnym przewidzianych w niej unormowań. W rezultacie „nowa” u.p.p. wprowadziła kilka istotnych zmian w stosunku do swojej poprzedniczki, tj. ustawy z 16 listopada 2000 r., odnoszących się zarówno do samych podmiotów objętych jej uregulowaniami, jak i nałożonych na nie obowiązków. Taki stan rzeczy, jak również wyjątkowo obszerny charakter przeprowadzonych zmian zmuszają do zawężenia problematyki podnoszonej w tym artykule jedynie do zakresu podmiotowego tej ustawy, a obowiązki nałożone na wybrane instytucje obowiąane zostana zaprezentowane przez pryzmat funkcjonowania tych podmiotów w polskim systemie przeciwdziałania praniu pieniędzy (art. 299 k.k.) ${ }^{12}$.

Zasadniczym celem rozważań podjętych w niniejszym artykule będzie bowiem nie tyle wskazanie na przeprowadzone już zmiany, ile przede wszystkich zasygnalizowanie tych kwestii, które z perspektywy potrzeby dostosowania polskich przepisów do unormowań unijnych wymagają stosownej nowelizacji. Jedynie gwoli wyjaśnienia wypada zaznaczyć, że podniesione w nim uwagi pozostają aktualne także w odniesieniu do procederu finansowania terroryzmu (art. 165a k.k.), skoncentrowanie się na praniu pieniędzy jest zaś uzasadnione w świetle praktycznego aspektu zagrożenia tym zjawiskiem ${ }^{13}$.

${ }^{7}$ Por. Michalska-Warias (2013): 61-67 i 70; Filipkowski, Pływaczewski (2007): 93-103.

${ }^{8}$ Ustawa z 1 marca 2018 r. weszła w życie 13 lipca 2018 r.

${ }^{9}$ Dz. Urz. UE nr L 335/1 z 17 grudnia 2009 r. oraz Dz. Urz. UE nr L 178/338 z 26 czerwca $2013 \mathrm{r}$.

${ }^{10}$ Dz. Urz. UE nr L 156/43.

${ }^{11}$ Dz. Urz. UE nr L 141/73.

${ }^{12}$ Ustawa z 6 czerwca 1997 r. - Kodeks karny, t.jedn.: Dz. U. 2019, poz. 1950.

${ }^{13}$ Por. Sprawozdanie Generalnego Inspektora Informacji Finansowej [GIIF] z wykonania ustawy z 1 marca 2018 r. o przeciwdziałania praniu pieniędzy oraz finansowaniu terroryzmu za rok 2018, Warszawa, marzec 2019 r.: 27. Wynika z niego, że w 2018 r. GIIR otrzymał 42766 


\section{ZMIANY W KATALOGU INSTYTUCJI OBOWIĄZANYCH}

Ustawa z 1 marca 2018 r. (wzorem u.p.p. z 16 listopada 2000 r.) przewiduje nadal trzy podstawowe kategorie podmiotów objętych jej unormowaniami, tj.: instytucje obowiązane, jednostki współpracujące ${ }^{14}$, a także organy informacji finansowej, którymi sa: Generalny Inspektor Informacji Finansowej (GIIF) oraz minister właściwy do spraw finansów publicznych jako naczelny organ informacji finansowej ${ }^{15}$. Ponadto u.p.p. ustanawia nowe podmioty, względem których na instytucjach obowiązanych spoczywają szczególne obowiązki związane ze stosowaniem środków bezpieczeństwa finansowego bądź wzmożonych środków takiego bezpieczeństwa ${ }^{16}$.

$\mathrm{W}$ odniesieniu do instytucji obowiąanych istotne novum $\mathrm{w}$ stosunku do swojej „poprzedniczki”, jakie wprowadziła u.p.p. z 1 marca 2018 r., stanowi poszerzenie katalogu takich podmiotó $\mathrm{w}^{17}$. W świetle obecnego stanu prawnego instytucjami obowiązanymi są zatem także m.in.: podmioty prowadzace działalność gospodarczą polegająca na świadczeniu usług w zakresie wymiany pomiędzy walutami wirtualnymi i środkami płatniczymi (pkt 12 art. 2 ust. 1 u.p.p.), przedsiębiorcy, niebędący innymi instytucjami obowiązanymi, świadczący usługi określone w art. 2 ust. 1 pkt 16 lit. a-e, a także przedsiębiorcy (w rozumieniu ustawy z 6 marca 2018 r. - Prawo przedsiębiorców) w zakresie, w jakim prowadzą działalność polegająca na udostępnianiu skrytek sejfowych (art. 2 ust. 1 pkt 24 u.p.p.). Ustawa z 1 marca 2018 r. w katalogu instytucji obowiązanych wymienia także instytucje pożyczkowe w rozumieniu ustawy z 12 maja 2011 r. o kredycie konsumenckim (art. 2 ust. 1 pkt 25 u.p.p.). W uzasadnieniu zabiegu legislacyjnego polegającego na „rozbudowaniu” wykazu instytucji obowiązanych podniesiono m.in., że objęcie tych podmiotów obowiązkami wynikającymi z przepisów AML/CTF było podyktowane potrzebą dostosowania do unormowań unijnych (zarówno „czwartej”, jak i „piątej” dyrektywy AML, tudzież wytycznymi FATF określonymi w „Guidance for a risk-based approach - Virtual Currencies” z czerwca 2015 r. $)^{18}$. W przypadku

informacji o pojedynczych transakcjach, których okoliczności mogą wskazywać na związek z popełnieniem przestępstwa (ang. Suspicious Transaction Reports - STR), w tym 42737 transakcji oznaczono jako mogące mieć związek z praniem pieniędzy (ang. Suspicious Transaction Reports on Money Laundering, STR-ML), a 29 transakcji - jako mogące mieć związek z finansowaniem terroryzmu (ang. Suspicious Transaction Reports on Terrorist Financing, STR-TF).

${ }^{14}$ Zgodnie z art. 2 ust. 2 pkt 8 u.p.p. jednostki współpracujące to organy administracji rządowej, organy jednostek samorządu terytorialnego oraz inne państwowe jednostki organizacyjne, a także NBP, KNF i NIK. O tym por. Jasiński (2013): 71-78 i powołana tam literatura.

15 Tryb powoływania oraz podstawowe kompetencje tych organów regulują art. 10-18 u.p.p.

16 Jasiński (2012): 77-78; Lizak (2018): 255-262.

${ }^{17}$ Katalog instytucji obowiązanych jest określony w art. 2 ust. 1 pkt 1-25 u.p.p. Obejmuje on m.in. podmioty takie, jak: banki, fundusze inwestycyjne, zakłady ubezpieczeń, pośredników ubezpieczeniowych, przedstawicieli zawodów prawniczych w określonym, przedsiębiorców prowadzacychy działalność kantorowa, pośredników w obrocie nieruchomościami, operatorów pocztowych, fundacje, stowarzyszenia.

${ }^{18}$ Druk nr 2233 - uzasadnienie. Sejm VIII kadencji. Dokument dostępny na stronie: <http:// www.sejm.gov.pl/Sejm8.nsf/druk.xsp?nr=2233> [dostęp: 21.01.2020]. 
zagrożeń dla rynku finansowego, jakie niesie obrót walutą wirtualna, istotne okazały się także doświadczenia zagranicznych jednostek analizy finansowej (Financial Intelligence Unit - FIU $\left.{ }^{19}\right)^{20}$.

Z kolei status instytucji obowiązanych utracili przedsiębiorcy prowadzący domy aukcyjne, antykwariaty, działalność w zakresie obrotu metalami lub kamieniami szlachetnymi i półszlachetnymi oraz prowadzący sprzedaż komisowa. W uzasadnieniu tej zmiany wskazano na niewielkie, z praktycznego punktu widzenia, ryzyko wykorzystania ich działalności dla potrzeb prania pieniędzy ${ }^{21}$. Jest to o tyle interesujace, że V dyrektywa AML poleca przywiazzywać szczególną wagę do nałożenia stosownych obowiązków na podmioty trudniące się rodzajami działalności o zbliżonym profilu. Mowa o podmiotach, które przeprowadzaja transakcje związane z ropą naftowa, bronia, metalami szlachetnymi, produktami tytoniowymi, artefaktami kulturowymi i innymi przedmiotami o znaczeniu archeologicznym, historycznym, kulturowym i religijnym lub o szczególnej wartości naukowej, a także kością słoniowa i gatunkami chronionymi, które na mocy zmiany IV dyrektywy AML należy uwzględniać w ramach „czynnika ryzyka związanego z produktami, usługami, transakcjami lub kanałami dostawy".

Warto przy tym przypomnieć, że już na gruncie u.p.p. z 16 listopada 2000 r. podnoszono, iż katalog instytucji obowiązanych (nawet w ówczesnym stanie prawnym) pozostawał niezupełny ${ }^{22}$, zwłaszcza jeżeli mieć na względzie obowiązujące regulacje wspólnotowe ${ }^{23}$. Nie uwzględniono w nim pewnych podmiotów, których działalność była uznawana przez przepisy unijne za stwarzającą realne zagrożenie procederem prania pieniędzy ${ }^{24}$.

Co jednak wydaje się najistotniejsze, to konieczność uwzględnienia w bieżącym katalogu instytucji obowiązanych zmian podyktowanych potrzebą dostosowania polskich przepisów do wymagań wynikających z V dyrektywy AML. W świetle jej postanowień status podmiotu obowiązanego powinni posiadać m.in. „biegli rewidenci, zewnętrzni księgowi oraz doradcy podatkowi” (co przewiduje już u.p.p. z 1 marca 2018 r.), ale nadto także, ,jakakolwiek inna osoba, która zobowiązuje się udzielić, bezpośrednio lub za pośrednictwem innych osób, z którymi ta inna osoba jest powiązana, pomocy materialnej, wsparcia lub porad w sprawach podatkowych w ramach podstawowej działalności gospodarczej lub zawodowej". Aktualnie instytucją obowiązaną są wprawdzie „instytucje pożyczkowe” (tj. podmioty, o których mowa w art. 2 ust. 1 pkt 25 u.p.p.), jak również przedsiębiorcy dokonujący płatności gotówkowych o równowartości 10000 euro, jednak nie jest to tożsame z zakresem podmiotowym wskazanym w V dyrektywie AML. Nie uwzględnia on - w pierwszym przypad-

19 Polską jednostką analityki finansowej jest GIIF.

${ }^{20}$ Druk nr 2233 - uzasadnienie. Sejm VIII kadencji.

${ }^{21}$ Druk nr 2233 - uzasadnienie. Sejm VIII kadencji. Potwierdzeniem tego były także statystyki i wypływające z nich wnioski na temat zagrożenia procederem prania pieniędzy, publikowane w corocznych sprawozdaniach GIIF z wykonania ustawy z 16 listopada $2000 \mathrm{r}$.

22 Wójcik (2002): 211-212.

23 Por. Niemierka, Smykla (2001): 98 i 113.

24 Por. Golonka (2008): 179-181. 
ku - podmiotów, których działalność lub czynności zawodowe nie ograniczają się do działalności pożyczkowej, w drugim zaś - poza zakresem pozostaja osoby niebędace przedsiębiorcami, a także dokonujące płatności w kwotach niższych niż równowartość 10000 euro. Stosownie do postanowień V dyrektywy AML należałoby także wprowadzić przepis odnoszący się do pośredników w obrocie nieruchomościami (posiadających już status instytucji obowiązanej), ale dotyczący ich działalności w charakterze pośredników w wynajmowaniu nieruchomości, który ograniczałby ich obowiązki do przypadków, w których: „miesięczny czynsz wynosi co najmniej 10000 euro”. Wreszcie luka, jaką należało usunaćc do 10 stycznia 2020 r., jest brak w u.p.p. przepisu przewidującego nałożenie obowiązków na podmioty trudniące się obrotem walutami wirtualnymi w zakresie, w jakim świadczą one usługi wymiany walut pomiędzy walutami wirtualnymi a walutami fiducjarnymi, tudzież podmioty będące dostawcami kont walut wirtualnych.

Waluty wirtualne i obrót nimi są uznawane za jedno z najbardziej aktualnych zagrożeń dla rynków finansowych z punktu widzenia możliwości wykorzystania ich do celu prania pieniędzy. Waluty takie, co warto przywołać w tym miejscu: „[...] bazują na złożonym systemie protokołów kryptograficznych" ${ }^{25}$. Obecnie najczęściej spotykaną w obrocie walutą wirtualną jest bitcoin. Jego istota polega na: „,...] wygenerowaniu kodu (szyfru) przy użyciu tzw. koparki (ang. excavator), to znaczy określonego programu i sprzętu komputerowego o wysokiej mocy obliczeniowej w sieci peer-to-peer"26. Definicję waluty wirtualnej wprowadzono także w u.p.p. z 1 marca 2018 r. Zgodnie z art. 2 ust. 2 pkt 26 u.p.p. przez pojęcie to należy rozumieć: „,[...] cyfrowe odwzorowanie wartości, które nie jest:

a) prawnym środkiem płatniczym emitowanym przez NBP, zagraniczne banki centralne lub inne organy administracji publicznej,

b) międzynarodowa jednostką rozrachunkową ustanawiana przez organizację międzynarodową i akceptowaną przez poszczególne kraje należące do tej organizacji lub z nią współpracujące,

c) pieniądzem elektronicznym w rozumieniu ustawy z 19 sierpnia $2011 \mathrm{r}$. o usługach płatniczych,

d) instrumentem finansowym w rozumieniu ustawy z 29 lipca 2005 r. o obrocie instrumentami finansowymi,

e) wekslem lub czekiem - oraz jest wymienialne w obrocie gospodarczym na prawne środki płatnicze i akceptowane jako środek wymiany, a także może być elektronicznie przechowywane lub przeniesione albo może być przedmiotem handlu elektronicznego". Ponadto przewidziano, iż wartości majątkowe w rozumieniu u.p.p. obejmuja nie tylko (jak dotychczas) prawa majątkowe lub inne mienie ruchome lub nieruchomości, środki płatnicze, instrumenty finansowe w rozumieniu ustawy z 29 lipca 2005 r. o obrocie instrumentami finansowymi, inne papiery wartościowe oraz wartości dewizowe, ale nadto także (obecnie) waluty wirtualne (art. 2 ust. 2 pkt 27 u.p.p.). Postępujący rozwój

${ }^{25}$ Dąbrowska (2016): 77-81.

${ }^{26}$ Dąbrowska (2016): 77-81. Por. także: Bala, Kopyściański, Srokosz (2016): 111-115. 
sektora usług finansowych i przede wszystkim wzajemne „przenikanie” się obszarów przepływu środków finansowych (zyski wygenerowane z transakcji „brudnymi” wartościami majątkowymi, pochodzącymi z transakcji dokonanej przy użyciu Bitcoina, moga być legalizowane za pośrednictwem usług bankowych ${ }^{27}$ ) sprawiaja, że zagrożenie wprowadzenia do obrotu finansowego środków „wypranych” przy użyciu waluty wirtualnej staje się bardzo realne. Zważywszy zaś na dynamikę rynku kryptowalut, konieczność stałego monitorowania tendencji, jakie na nim panuja, staje się oczywista. Tym samym proponowane przez UE zmiany w IV dyrektywie AML maja na celu dostosowanie bieżących rozwiązań prawnych do ryzyka, jakie niesie ze sobą obecnie wykorzystanie waluty wirtualnej w działalności przestępczej.

Wobec tego prawodawca unijny w V dyrektywie AML poszerzył zakres stosowania dyrektywy (UE) 2015/849 na podmioty zajmujace się świadczeniem usług wymiany walut pomiędzy walutami wirtualnymi a walutami fiducjarny$\mathrm{mi}^{28}$, a także dostawców kont walut wirtualnych. Można jedynie przypomnieć w tym miejscu, że pieniądz fiducjarny charakteryzuje się tym, że jego wartość opiera się na wierze użytkownika w możliwość wymiany go w każdym czasie na podstawową wartość i nie jest powiązana z wartością nośnika ${ }^{29}$. Takim pieniądzem jest również pieniądz elektroniczny, stanowiący swoisty: „elektroniczny surogat monet i banknotów”, który jest przechowywany na elektronicznym nośniku, np. karcie mikroprocesorowej (karta pre-paid, uprzednio opłaconej, jak np. karta telefoniczna) lub w pamięci komputera (network, software money), i przeznaczony jest głównie do dokonywania płatności elektronicznych o ograniczonej wartości ${ }^{30}$. Pieniądz fuducjarny jest uznawany za tożsamy z pieniądzem sensu stricto (gotówkowym). Jako taki stanowi zatem prawny środek płatniczy (ang. legal tender) i charakteryzuje się między innymi powszechnością jego akceptacji (połączona z obowiązkiem jego przyjmowania, skoro odmowa przyjęcia zapłaty prowadzi do popadnięcia dłużnika w zwłokę) oraz zdolnością do umarzania zobowiązań ${ }^{31}$.

„Piąta” dyrektywa AML wprowadza także definicje „dostawcy konta waluty wirtualnej”, którym zgodnie z art. 1 pkt $2 \mathrm{~d}$ jest: „podmiot świadczaccy usługi polegajace na przechowywaniu prywatnych danych uwierzytelniających w imieniu swoich klientów na potrzeby posiadania, przechowywania i przekazywania walut wirtualnych". Odpowiednika takiej definicji brak w polskich regulacjach. Należy zatem zgłosić stosowny postulat wprowadzenia adekwatnego uregulowania. Chociaż sam prawodawca unijny przyznaje, że zmiany w tym zakresie nie rozwiążą całkowicie problemu anonimowości

${ }^{27}$ Mowa o systemie z dwukierunkowym przepływem pieniężnym, w którym wirtualna waluta może być wymieniana na inne waluty bez ograniczeń, czego przykładem jest właśnie bitcoin, który jest walutą wymienialną w elektronicznych kantorach lub na giełdach - por. Mackiewicz, Musiał (2014): 136-139.

${ }_{28}$ Więcej na temat zagrożenia dla obrotu finansowego - por. Bala, Kopyściański, Srokosz (2016): 143-144.

29 Por. Jurkowska [w:] Brodecki (2004): 273.

30 Jurkowska [w:] Brodecki (2004): 273. Por. także: Cyman (2013): 33-44.

${ }^{31}$ Cyman (2013): 54, a także: Srokosz (2011): 212-213. 
transakcji z użyciem walut wirtualnych, „[...] ponieważ duża część środowiska posługującego się tymi walutami pozostanie anonimowa ze względu na fakt, że użytkownicy mogą dokonywać transakcji również bez pośrednictwa takich dostawców"32, niemniej wskazuje on na to, iż krajowe jednostki analityki finansowej powinny być w stanie uzyskać informacje pozwalajace im na powiązanie adresu waluty wirtualnej z tożsamościąjej właściciela. Zatem jako środek służący przeciwdziałaniu praniu pieniędzy prawodawca unijny zalecił: „obniżenie istniejaccych limitów dla anonimowych kart przedpłaconych ogólnego zastosowania oraz zidentyfikowanie klienta w przypadku zdalnych transakcji płatniczych w przypadku, gdy kwota transakcji przekracza 50 euro", z zastrzeżeniem, że należy mieć przy tym na względzie także: „potrzeby konsumentów dotyczące korzystania z instrumentów przedpłaconych ogólnego zastosowania”. Wobec czego znowelizowane przepisy nie powinny uniemożliwić im korzystania z takich instrumentów: „[...] w interesie włączenia społecznego i włączenia w rynek finansowy" (jak wskazano w V dyrektywie AML).

Należy wobec tego postulować objęcie zakresem polskiej regulacji zarówno usług świadczonych przez podmioty zajmujące się wymianą pomiędzy waluta wirtualną a fiducjarna, jak i podmiotów, które są dostawcami kont waluty wirtualnej.

\section{INNE PODMIOTY UCZESTNICZĄCE W SYSTEMIE PRZECIWDZIAŁANIA PRANIU PIENIĘDZY W ŚWIETLE POSTANOWIEŃ USTAWY Z 1 MARCA 2018 ROKU}

Zakres podmiotowy ustawy z 1 marca 2018 r. pozwala na wskazanie innych poza wspomnianymi powyżej, kategorii podmiotów, w stosunku do których na instytucjach obowiązanych spoczywają szczególne powinności. Niektóre z nich, jak np. osoby będące beneficjentami rzeczywistymi, przewidywała już ustawa z 16 listopada 2000 r. w ostatnich latach swojego obowiązywania, chociaż czyniła to ona $\mathrm{w}$ nieporównywalnie węższym zakresie niż obecnie obowiąująca. Inne podmioty, takie jak: kadra kierownicza wyższego szczebla, osoby zajmujące eksponowane stanowiska polityczne oraz członkowie ich rodzin, a także osoby znane jako bliscy współpracownicy osób zajmujących eksponowane stanowiska polityczne ${ }^{33}$ bądź klienci instytucji obowiązanych, zostały wprowadzone dopiero do u.p.p. z 1 marca 2018 r. tudzież objęte stosownymi regulacjami co do oceny ryzyka ich wykorzystania do celów prania pieniędzy.

Uwzględnienie beneficjentów rzeczywistych w u.p.p. z 1 marca 2018 r. stanowi realizację postulatów płynących przede wszystkim z IV dyrektywy AML. „Piąta” dyrektywa AML wprowadza jednak zmiany, w szczególności dotyczące wykonywania obowiązków nałożonych na instytucje obowiązane w stosunku do takich osób. Warto zauważyć, że krajowy legislator podsta-

32 Preambuła, pkt 9 V dyrektywy AML.

33 Więcej o tym - por. Jasiński (2012): 32-58. 
wowymi przesłankami uzasadniającymi nadanie danej osobie lub osobom fizycznym statusu beneficjenta rzeczywistego uczynił sprawowanie przez taką osobę lub osoby kontroli nad innym podmiotem, a także możliwość wywierania przez nią decydującego wpływu na decyzje podejmowane przez inny podmiot - de facto będący klientem instytucji obowiązanej. Taki wniosek wypływa z treści definicji legalnej beneficjenta rzeczywistego, zawartej w art. 2 ust. 2 pkt 1 u.p.p. ${ }^{34}$ Jak podniesiono w uzasadnieniu projektu u.p.p., ostateczny kształt tej definicji został podyktowany potrzebą położenia w niej nacisku na możliwość sprawowania kontroli oraz posiadania uprawnień pozwalajacych na realny wpływ na podejmowanie decyzji przez inny podmiot, a także okolicznościa, że: „[...] instytucja beneficjenta rzeczywistego [...] jest powszechnie identyfikowana w państwach członkowskich UE jako jedno z najbardziej skomplikowanych i dyskusyjnych zagadnień związanych ze stosowaniem przepisów o przeciwdziałaniu praniu pieniędzy oraz finansowaniu terroryzmu" ${ }^{35}$.

Warto także dostrzec, iż ustawa z 1 marca 2018 r. zawęża krag podmiotów zobligowanych do identyfikacji beneficjenta rzeczywistego (art. 58 u.p.p.). Jak podniesiono w uzasadnieniu projektu u.p.p., powodem tego jest nałożenie przez art. 30 ust. 1 dyrektywy 2015/849 takiej powinności jedynie na „podmioty o charakterze korporacyjnym i inne podmioty prawne”. W stosunku do nich w prawie wspólnotowym przewidziano konieczność dysponowania przez instytucje zobowiązane: „odpowiednimi, dokładnymi i aktualnymi informacjami o ich beneficjentach rzeczywistych", w tym zawierajacymi szczegółowe informacje o stosunkach łączących te podmioty z beneficjentami rzeczywistymi. Natomiast zważywszy na obowiązujące w naszym kraju przepisy, pojęcie podmiotów korporacyjnych wydaje się wysoce niedookreślone ${ }^{36}$. Dostrzegł to zreszta sam projektodawca, który wywiódł, że: „Powszechnie przyjmuje się podział podmiotów prawa na oparte na substracie osobowym podmioty typu korporacyjnego oraz na oparte na substracie majatkowym podmioty typu zakładowego. [...] Powszechnie przyjmuje się, iż podmioty

${ }^{34}$ Definicja beneficjenta rzeczywistego jest zawarta w art. 2 ust. 2 pkt 1 . W świetle tego przepisu przez pojęcie to rozumie się: „osobę fizyczną lub osoby fizyczne sprawujące bezpośrednio lub pośrednio kontrolę nad klientem poprzez posiadane uprawnienia, które wynikają z okoliczności prawnych lub faktycznych, umożliwiające wywieranie decydującego wpływu na czynności lub działania podejmowane przez klienta, lub osobę fizyczną lub osoby fizyczne, w imieniu których sa nawiazywane stosunki gospodarcze lub przeprowadzana jest transakcja okazjonalna, w tym: a) w przypadku klienta będącego osobą prawną inną niż spółka, której papiery wartościowe sa dopuszczone do obrotu na rynku regulowanym podlegającym wymogom ujawniania informacji wynikającym z przepisów prawa Unii Europejskiej lub odpowiadającym im przepisom prawa państwa trzeciego, b) w przypadku klienta będącego trustem: założyciela, powiernika, nadzorcę, jeżeli został ustanowiony, beneficjenta, inną osobę sprawującą kontrolę nad trustem, c) w przypadku klienta będącego osobą fizyczną prowadząca działalność gospodarcza, wobec którego nie stwierdzono przesłanek lub okoliczności mogących wskazywać na fakt sprawowania kontroli nad nim przez inną osobę fizyczną lub osoby fizyczne, przyjmuje się, że taki klient jest jednocześnie beneficjentem rzeczywistym". Na gruncie u.p.p. z 16 listopada 2000 r. na temat tej kategorii podmiotów - por. Bieniek (2010): 227.

${ }^{35}$ Por. uzasadnienie do projektu u.p.p. - druk 2233.

${ }^{36}$ Por. uzasadnienie do projektu u.p.p. - druk 2233: 32-33. 
prawa typu korporacyjnego sa zbiorowościami osób związanych z tym podmiotem stosunkiem członkostwa, realizującymi wspólne cele oraz decydujaccymi o celach i aktywności korporacji” ${ }^{37}$. Majacc na uwadze powyższe, jak również ideę podejścia opartego na ocenie ryzyka, jaka przyświeca całej polityce przeciwdziałania praniu pieniędzy, rodzimy prawodawca uznał za zasadne nałożenie obowiązku identyfikacji beneficjentów rzeczywistych tylko na te „podmioty korporacyjny”, „[...] których konstrukcja pozwala na ukrycie tożsamości osób fizycznych faktycznie wywierających decydujący wpływ na działania podejmowane przez takie podmioty i w stosunku do których zidentyfikowano ryzyko wykorzystania tych podmiotów w celu ukrycia tożsamości przestępców uczestniczących w procederze prania pieniędzy"38. Dodatkowo odwołał się on do praktyki GIIF, z której wynika, że: ,[...] nie każdy typ spółki znany prawu polskiemu w tym samym stopniu jest narażony na wykorzystanie w przestępczym procederze". Stanowiło to podstawę do wyłączenia spod obowiązku identyfikowania beneficjentów rzeczywistych spółki partnerskiej oraz spółki publicznej ${ }^{39}$. W odniesieniu do tej pierwszej, wyłączenie uzasadnione jest specyficznym przeznaczeniem spółki partnerskiej jako podmiotu utworzonego przez wspólników w celu wykonywania wolnego zawodu, co do spółki publicznej zaś: „odrębnie określonymi obowiązkami o charakterze informacyjnym, jak i znaczną fluktuacją akcjonariatu spółek publicznych" ${ }^{40}$.

Takie uzasadnienie przyjętego rozwiązania prawnego, chociaż niewątpliwie pozytywnie odebrane przez podmioty wyłączone spod omawianego obowiązku, nie może nie zastanawiać. Argumentacja podniesiona w uzasadnieniu projektu u.p.p. i przytaczana w literaturze przedmiotu ${ }^{41}$, z której wynika, że wspomniane dwa typy spółek stwarzają relatywnie niższe ryzyko wykorzystania ich działalności do prania pieniędzy teoretycznie nie nasuwa obiekcji. Może jednak budzić zastrzeżenia np. w kontekście objęcia obowiązkiem identyfikacji beneficjanta rzeczywistego przedstawicieli wolnych zawodów, którzy wykonują działalność w ramach „podmiotu korporacyjnego”, tj. w istocie w innej niż spółka partnerska formie organizacyjno-prawnej. Nie wydaje się, aby istniały wystarczająco przekonujące argumenty, które przemawiałyby za takim podejściem, w szczególności dotyczące na przykład złożonego charakteru prowadzonych spraw lub gałęzi prawa, jakiej one w przeważającej mierze dotycząca. Należy mieć wszakże na uwadze to, iż z założenia zakres obowiązków nałożonych na takie podmioty przez u.p.p. został ograniczony, co jest podyktowane specyfiką czynności podejmowanych przez przedstawicieli zawodów zaufania publicznego (por. art. 2 ust. 1 pkt 14 u.p.p.) ${ }^{42}$. Natomiast w odniesieniu do spółki publicznej motywy wyłączenia jej na mocy

37 Ibidem.

38 Ibidem.

39 Chodzi o spółki akcyjne w rozumieniu ustawy z 29 lipca 2005 r. o ofercie publicznej i warunkach wprowadzania instrumentów finansowych do zorganizowanego systemu obrotu oraz o spółkach publicznych, t.jedn.: Dz. U. 2019, poz. 623.

40 Ibidem: 33-34.

${ }^{41}$ Por. Grynfelder [w:] Kapica (2020): komentarz do art. 58 u.p.p. z 1.03.2018 r.

42 Por. Filipkowski, Prokop (2006): 69-83. 
art. 58 u.p.p. wydają się racjonalne, zwłaszcza w kontekście oczekiwanej, obligatoryjnej od 1 stycznia dematerializacji akcji ${ }^{43}$.

Od 13 października 2019 r. działa w naszym kraju system teleinformatyczny - Centralny Rejestr Beneficjentów Rzeczywistych (art. 55 i n. u.p.p.), powołany do życia na mocy rozporządzenia MF z 16 maja 2018 r. ${ }^{44}$ Spółki objęte takim obowiązkiem przesyłają zgłoszenie o beneficjencie rzeczywistym za pośrednictwem strony internetowej, której identyfikator URI jest zamieszczony w Biuletynie Informacji Publicznej na stronie podmiotowej urzędu obsługującego ministra właściwego do spraw finansów publicznych. Zgłoszenie to jest szyfrowane w sposób automatyczny w systemie teleinformatycznym wykorzystywanym przez tego ministra do przyjmowania zgłoszeń ( 22 ww. rozporządzenia). Sposób organizacji Rejestru stanowi zarazem realizację postulatów płynących z V dyrektywy AML. Kładzie ona jednak dodatkowo nacisk na konieczność zapewnienia publicznego dostępu do danych zgromadzonych w Rejestrze. Zdaniem prawodawcy wspólnotowego umożliwia to m.in.: „[...] większą kontrolę informacji przez społeczeństwo obywatelskie, w tym przez prasę lub organizacje społeczeństwa obywatelskiego", a także przyczynia się do utrzymania zaufania do uczciwości transakcji finansowych oraz do systemu finansowego. Stwierdzenie to, chociaż bez wątpienia słuszne, może budzić uzasadnione obiekcje z praktycznego punktu widzenia, zwłaszcza ze strony podmiotów, na temat których - co warto w tym miejscu odnotować - bez ich wiedzy (por. art. 65 u.p.p.) gromadzone sa owe dane, zatem nie sposób byłoby poprzeć jakichkolwiek działań podjętych w tym kierunku przez polskiego prawodawcę.

Zakres podmiotowy u.p.p. z 1 marca 2018 r. tworzą obecnie także klienci instytucji obowiązanych. Już na gruncie ustawy z 16 listopada 2000 r. ujmowano ich niekiedy w ramach tego zakresu ${ }^{45}$. Niemniej wobec braku definicji legalnej „klienta”, a tym samym także określenia, jakie podmioty - z przyznanymi im prawami lub obowiązkami - należy uznawać za „klienta”, traktowanie klientów jako kategorii podmiotów objętych regulacjami u.p.p. z 16 listopada 2000 r. nie było trafne, w każdym zaś wypadku miało ono bardziej dogmatyczny wymiar niż praktyczne znaczenie. W żadnym razie nie znajdowało ono stosownego oparcia $\mathrm{w}$ przepisach tej ustawy. W obecnym stanie prawnym określono expressis verbis, jakie podmioty (i pozostajace, w jakich relacjach z instytucją obowiązana) są klientami tych instytucji (art. 2 pkt 10 u.p.p.) ${ }^{46}$.

${ }^{43}$ Ustawa z 30 sierpnia 2019 r. o zmianie ustawy Kodeks spółek handlowych oraz niektórych innych ustaw, Dz. U. 2019, poz. 1798.

${ }^{44}$ Por. rozporządzenie Ministra Finansów z 16 maja 2018 r. w sprawie zgłaszania informacji o beneficjentach rzeczywistych wydane na podstawie art. 62 u.p.p., Dz. U. 2018, poz. 968.

${ }^{45}$ Por. np. Wójcik (2002): 214.

${ }^{46}$ Zgodnie z art. 2 pkt 10 u.p.p. przez pojęcie klienta rozumie się osobę fizyczna, osobę prawną lub jednostkę organizacyjną nieposiadającą osobowości prawnej, której instytucja obowiązana świadczy usługi lub dla której wykonuje czynności wchodzące w zakres prowadzonej przez nia działalności zawodowej, w tym z którą instytucja obowiązana nawiązuje stosunki gospodarcze lub na zlecenie której przeprowadza transakcję okazjonalna; w przypadku umowy ubezpieczenia przez klienta instytucji obowiązanej rozumie się ubezpieczającego. 
Natomiast nieuwzględnienie osób zajmujących eksponowane stanowiska polityczne było istotnym i podnoszonym w piśmiennictwie brakiem ustawy z 16 listopada 2000 r. ${ }^{47}$ Podmioty takie, już pod rządami tej ustawy, należało objąć wzmożonymi zasadami należytej ostrożności, co wynikało wprost z art. 13 ust. 4 dyrektywy 2005/60/WE ${ }^{48}$. Jak zwracał uwagę The Financial Action Task Force (FATF) w 40 Rekomendacjach, istnieje wysokie ryzyko tego, że osoby takie z racji piastowanej funkcji lub zajmowanego stanowiska, a także członkowie ich rodzin lub ich bliscy współpracownicy moga dopuścić się czynu bazowego (w szczególności o charakterze korupcyjnym) ${ }^{49}$, a następnie wprowadzenia do obrotu korzyści majątkowych osiagniętych w wyniku tego czynu ${ }^{50}$. W aktualnym stanie prawnym przewidziano względem takich osób stosowanie wzmożonych środków bezpieczeństwa finansowego tudzież określono w art. 2 ust. 2 pkt 3, 11 i 12 u.p.p., jakie osoby należy uznawać za takowe, za członków ich rodzin, jak również za ich bliskich współpracowników ${ }^{51}$.

Ustawa z 1 marca 2018 r. wprowadza także nowe regulacje odnoszące się do „kadry kierowniczej wyższego szczebla”, odpowiedzialnej za wykonywanie obowiązków określonych w ustawie. „Kadra kierownicza wyższego szczebla”, w myśl art. 2 ust. 1 pkt 9 u.p.p., to członkowie zarządu, dyrektorzy lub pracownicy instytucji obowiązanych, posiadający wiedzę z zakresu ryzyka prania pieniędzy oraz finansowania terroryzmu związanego z działalnością instytucji obowiązanej oraz podejmujacy decyzje majace wpływ na to ryzyko ${ }^{52}$. Ponadto nadal aktualny pozostaje obowiązek wyznaczenia pracownika zajmujacego kierownicze stanowisko, odpowiedzialnego za zapewnienie zgodności działalności instytucji obowiązanej oraz jej pracowników i innych osób wykonujących czynności na rzecz tej instytucji obowiązanej z przepisami u.p.p. (art. 8 u.p.p.).

Ustawa z 1 marca 2018 r. ustanawia także nowe ciało o charakterze opiniodawczo-doradczym, działające przy GIIF, tj. Komitet Bezpieczeństwa Finansowego. Zastapił on funkcjonujący uprzednio Międzyresortowy Komitet Bezpieczeństwa Finansowego (KBF), z tym że posiada szerszy zakres zadań od „poprzednika” (art. 19 u.p.p.). Ponadto doprecyzowano, kto wchodzi w skład KBF (art. 20 u.p.p.).

${ }^{47}$ Por. Golonka (2009): 112.

${ }^{48}$ Dyrektywa Parlamentu Europejskiego i Rady 2005/60/WE z 26 października 2005 r. $\mathrm{w}$ sprawie przeciwdziałania korzystaniu z systemu finansowego w celu prania pieniędzy oraz finansowania terroryzmu, Dz. Urz. UE, L nr 309 z 25 listopda 2005 r.

${ }^{49}$ Por. The Financial Action Task Force document: Best practices. Paper on the use of the FATF 1recommendations to combat Corruption, FATF 2013, s. 3-31. Dokument dostępny na: < https:/www.google.com/url?sa=t\&rct=j\&q=\&esrc=s\&source=web\&cd=4\&cad=rja\&uact=8\&ved=2ahUKEwj3p4-y-O_mAhUF-yoKHS3VAWIQFjADegQIBBAC\&url=http\%3A\%2F\%2Fwww . fatf-gafi.org $\% 2$ Fmedia $\% 2$ Ffatf $\% 2$ Fdocuments $\% 2$ Frecommendations $\% 2$ FBPP-Use-of-FATF-Recs-Corruption.pdf\&usg=AOvVaw154hsAv3QWnwfBmGaQnTU3> [dostęp: 6.01 .2020 r.]. W kontekście przestępczości zorganizowanej - por. Filipkowski (2011): 187-198 i 200-208.

50 Por. Kluczyński (2011): 177-197.

51 O tym: Jasiński (2012): 40-56, 92-103.

52 Zgodnie z art. 7 u.p.p. W przypadku instytucji obowiązanej, w której działa zarząd lub inny organ zarządzający, wyznacza się spośród członków tego organu osobę odpowiedzialną za wdrażanie obowiązków określonych w ustawie. 


\section{PODSUMOWANIE}

Uchwalenie ustawy z 1 marca 2018 r. o przeciwdziałaniu praniu pieniędzy oraz finansowaniu terroryzmu stanowi głównie wyraz realizacji postulatu dostosowania rodzimych przepisów do regulacji unijnych. Dotyczy to w szczególności dyrektywy 2015/849, która wywarła najbardziej znaczący wpływ na kształt przepisów obowiązujących w naszym kraju. Uchwalenie nowej ustawy zamiast wprowadzania kolejnych nowelizacji do obowiązującej wówczas ustawy z 16 listopada 2000 r., należy ocenić pozytywnie. Taka nowelizacja zważywszy na zakres zmian wprowadzonych za sprawa IV dyrektywy AML, byłaby w istocie wyjątkowo obszerna. $\mathrm{Z}$ uwagi na potrzebę zmodyfikowania modelu przeciwdziałania praniu pieniędzy (opartego na RBA) rodziłaby także obawy o zapewnienie wewnętrznej spójności na gruncie u.p.p. z 16 listopada 2000 r. Zarazem jednak ratio legis, która jest dostosowanie polskich przepisów do unormowań unijnych, nie może pozostawać bez wpływu także na kształt przepisów u.p.p. z 1 marca 2018 r. Tymczasem, jak dowodzą zaprezentowane wyżej wywody, nasz prawodawca nie w pełni sprostał tym oczekiwaniom.

Pozwalaja one bowiem na wysunięcie wniosku, że część postanowień V dyrektywy AML nie doczekała się wdrożenia do krajowej regulacji. Należałoby wobec tego postulować między innymi uzupełnienie katalogu instytucji obowiązanych o inne osoby (niż tylko podmioty zawodowo trudniące się doradztwem finansowym oraz podatkowym), ,jeżeli zobowiazują się one udzielić, bezpośrednio lub za pośrednictwem innych osób, z którymi ta inna osoba jest powiazzana, pomocy materialnej, wsparcia lub porad w sprawach podatkowych w ramach podstawowej działalności gospodarczej lub zawodowej”; objęcie obowiązkami wszystkich podmiotów (nie tylko posiadających status przedsiębiorcy), jeżeli dokonują płatności gotówkowych o równowartości 10000 euro; wprowadzenie przepisu odnoszacego się do pośredników nieruchomości, który ograniczałby ich obowiązi do przypadków, w których: „miesięczny czynsz wynosi co najmniej 10000 euro", w zakresie działalności polegającej na wynajmowaniu nieruchomości. Wreszcie luka, którą należałoby usunąć, jest brak przepisu przewidującego nałożenie obowiązków na podmioty trudniące się obrotem walutami wirtualnymi w zakresie, w jakim świadczą one usługi związane z wymiana pomiędzy walutami wirtualnymi a fiducjarnymi tudzież na podmioty będacy dostawcami kont walut wirtualnych.

Nie sposób nie wspomnieć także o kwestii terminowości wywiązywania się przez Polskę ze zobowiązań unijnych i terminie na implementację V dyrektywy AML, który upłynął 10 stycznia 2020 r. Należałoby wobec tego oczekiwać, że nasz prawodawca niezwłocznie pokusi się o stosowną nowelizację u.p.p., spóźnioną co prawda, ale pozwalająca na zachowanie zgodności z obowiązujacymi przepisami unijnymi.

Na zakończenie warto także zasugerować, aby w przyszłości nasz prawodawca okres przewidziany na transponowanie do krajowego porządku prawnego aktów unijnych poświęcił na opracowanie stosownych zmian w obowiazujących przepisach. Postulat ten jest aktualny zwłaszcza w kontekście upływającego 3 grudnia 2020 r. terminu implementacji VI dyrektywy AML. 
Takie podejście pozwoliłoby na uniknięcie sytuacji podobnej do tej na gruncie V dyrektywy AML, a która naraża Polskę na zarzut niewywiązania się ze zobowiązań wobec UE.

Anna Golonka

Uniwersytet Rzeszowski

agolonka@ur.edu.pl

https://orcid.org/0000-0002-0199-2203

Bala., S., Kopyściański, T., Srokosz, W. (2016). Kryptowaluty jako elektroniczne instrumenty płatnicze bez emitenta. Aspekty informatyczne, ekonomiczne i prawne. Wrocław.

Bieniek, B. (2010). Pranie pieniędzy w prawie międzynarodowym, europejskim oraz polskim. Warszawa.

Cyman, D. (2013). Elektroniczne instrumenty płatnicze a bezpieczeństwo uczestników rynku finansowego. Warszawa.

Dąbrowska, J. (2017). Charakter prawny bitcoin. Studia i Artykuły 1: 77-81.

Filipkowski, W. (2011). Systemy przeciwdziałania i zwalczania przestępczości zorganizowanej, [w:] E.W. Pływaczewski (red.), Przestępczość zorganizowana. Warszawa: 187-198 i 200-208.

Filipkowski, W., Pływaczewski, E.W. (2003) Wybrane inicjatywy międzynarodowe w zakresie przeciwdziałania praniu brudnych pieniędzy, [w:] A. Adamski (red.) Przestępczość gospodarcza z perspektywy Polski i Unii Europejskiej. Materiały z Międzynarodowej Konferencji Naukowej-Mikołajki, 26-28 września 2002. TNOiK, Toruń: 359-362.

Filipkowski, W., Pływaczewski, E.W. (2007). Standardy przeciwdziałania procederowi prania pieniędzy. Państwo i Prawo 62(10): 93-103.

Filipkowski, W., Prokop, K. (2006). Wolne zawody prawnicze a przeciwdziałanie praniu pieniędzy. Państwo i Prawo 61(2): 69-83.

Golonka, A. (2009). „Kolejna” dyrektywa unijna w sprawie przeciwdziałania praniu pieniędzy czas na ocenę dostosowania polskich regulacji prawnych. Studia Europejskie CE UW 1: 112.

Golonka, A. (2008). Prawnokarne zagadnienia przeciwdziałania wprowadzania do obrotu wartości majątkowych pochodzących z nielegalnych lub nieujawnionych źródeł. Rzeszów.

Grynfelder, J. (2010). [w:] W. Kapica (red.), Przeciwdziałanie praniu pieniędzy oraz finansowaniu terroryzmu. Komentarz. Warszawa (dokument Lex).

Jasiński, W. (2012). Osoby na eksponowanych stanowiskach politycznych. Przeciwdziałanie korupcji i praniu pieniędzy. Warszawa.

Jasiński, W. (2013). System przeciwdziałania i zwalczania prania pieniędzy, [w:] Proceder prania pieniędzy i jego implikacje. Warszawa: 71-78.

Jurkowska, A. (2004). [w:] Z. Brodecki (red.), Finanse. Warszawa.

Kluczyński, M. (2011). Politically Exposed Person, czyli osoba zajmująca eksponowane stanowisko polityczne jako klient o podwyższonym stopniu ryzyka. Przegląd Bezpieczeństwa Wewnętrznego 5: 177-197.

Lizak, R. (2018). Pranie pieniędzy w prawie polskim na tle europejskim, międzynarodowym i amerykańskim. Warszawa.

Mackiewicz, P., Musiał, M. (2014). Rozwój wirtualnych systemów monetarnych. Nauki o Finansach 1: 136-139.

Michalska-Warias, A. (2013). Pranie pieniędzy w prawie międzynarodowym i prawie Unii Europejskiej, [w:] E.W. Pływaczewski, Proceder prania pieniędzy i jego implikacje. Warszawa: $61-70$.

Niemierka, S., Smykla, B. (2001). Przeciwdziałanie praniu pieniędzy w bankach - aspekty prawne. Warszawa.

Pływaczewski, E.W. (2002). Przeciwdziałanie praniu brudnych pieniędzy z perspektywy międzynarodowej. Państwo i Prawo 57(8): 43-52.

Srokosz, W. (2011). Instytucje parabankowe w Polsce. Warszawa.

Wójcik, J.W. (2002). Pranie pieniędzy. Kryminologiczna i kryminalistyczna ocena transakcji podejrzanych. Warszawa. 


\section{THE SUBJECTIVE SCOPE OF THE ANTI-MONEY LAUNDERING ACT IN THE LIGHT OF THE AMENDED PROVISIONS}

\section{S u m m a r y}

This study is devoted to issues associated with counteracting money laundering. The analysis of the current regulations forms the basis for presenting the changes in the system of money laundering prevention that were introduced by the Act of 1 March 2018 on Counteracting Money Laundering and Terrorist Financing. At the same time, its entry into force is an expression of the implementation of EU obligations related to the need to implement the AML IV and V Directive in the national legal order. This enables both the presentation of applicable regulations and the assessment of the adaptation of Polish provisions to applicable EU regulations. The issue is all the more important because some provisions of the 'Fifth' AML Directive have been not transposed into the national Act, despite the deadline expiring on 10 January 2020. This justifies putting forward the appropriate de lege ferenda postulates. At the same time, due to the broad nature of the issue discussed in this study, the arguments made are limited to the subjective scope of the Act of 1 March 2018.

Keywords: money laundering; EU directive; obligated institution; virtual currency; real beneficiary 